AperTO - Archivio Istituzionale Open Access dell'Università di Torino

\title{
Injured cardiomyocytes promote dental pulp mesenchymal stem cell homing
}

\section{This is the author's manuscript}

Original Citation:

\section{Availability:}

This version is available http://hdl.handle.net/2318/142933

since 2016-05-30T12:13:13Z

Published version:

DOI:10.1016/j.bbagen.2014.03.005

Terms of use:

Open Access

Anyone can freely access the full text of works made available as "Open Access". Works made available under a Creative Commons license can be used according to the terms and conditions of said license. Use of all other works requires consent of the right holder (author or publisher) if not exempted from copyright protection by the applicable law. 


\section{(3) \\ UNIVERSITÀ DEGLI STUDI DI TORINO}

This Accepted Author Manuscript (AAM) is copyrighted and published by Elsevier. It is posted here by agreement between Elsevier and the University of Turin. Changes resulting from the publishing process - such as editing, corrections, structural formatting, and other quality control mechanisms may not be reflected in this version of the text. The definitive version of the text was subsequently published in Biochimica et Biophysica Acta (BBA) - General Subjects, Volume 1840, Issue 7, July 2014, Pages 2152-2161, http://dx.doi.org/10.1016/j.bbagen.2014.03.005.

You may download, copy and otherwise use the AAM for non-commercial purposes provided that your license is limited by the following restrictions:

(1) You may use this AAM for non-commercial purposes only under the terms of the CC-BY-NC-ND license.

(2) The integrity of the work and identification of the author, copyright owner, and publisher must be preserved in any copy.

(3) You must attribute this AAM in the following format: Creative Commons BY-NC-ND license (http://creativecommons.org/licenses/by-nc-nd/4.0/deed.en), http://dx.doi.org/10.1016/j.bbagen.2014.03.005 
"Injured cardiomyocytes promote dental pulp mesenchymal stem cell homing"

F. Di Scipio ${ }^{1 *}$, A.E. Sprio ${ }^{1 *}$, A. Folino ${ }^{1}$, M.E. Carere ${ }^{1}$, P. Salamone ${ }^{1}$, Z. Yang ${ }^{1}$, M. Berrone $^{2}$, M. Prat ${ }^{3}$, G. Losano ${ }^{4}$, R. Rastaldo ${ }^{1,5}$, G.N. Berta ${ }^{1,5}$

Affiliation:

${ }^{1}$ University of Turin, Department of Clinical and Biological Sciences, 10043, Orbassano, Turin, Italy

${ }^{2}$ San Luigi Gonzaga Hospital, Odontostomatology Division, 10043, Orbassano, Turin, Italy.

${ }^{3}$ Università del Piemonte Orientale "Amedeo Avogadro", Department of Health Sciences, 28100. Novara, Italy

${ }^{4}$ University of Turin, Department of Neuroscience, Physiology Division, 10125 Turin, Italy

${ }^{5}$ National Institute of Cardiovascular Research, 40126, Bologna, Italy (INRC)

* These Authors contributed equally at this paper

keywords: dental pulp stem cell; cardiac ischemia, cell migration, hypoxic cardiomyocyte

Corresponding author:

Giovanni N. Berta, Ph.D,

Department of Clinical and Biological Sciences

University of Turin,

reg Gonzole 10, 10043 Orbassano (TO) - Italy

Tel: +390116705446; fax: +390119038639

E-mail: giovanni.berta@unito.it 
Abstract

Background: The heart is unable to regenerate its tissues after severe injuries. Stem cell therapy appears to be one of the most promising approaches, though preclinical results are hitherto contradictory and clinical trials scanty and/or limited to phase-l. The limited knowledge about stem cell early homing in infarcted cardiac tissues can concur to this scenario.

Methods: the stem cell migration was assessed in in-vitro and ex-vivo models of heart ischemia, employing a rat dental pulp stem cell line (MUR-1) that shares the same ontogenic progenitors with portions of the heart, expresses markers typical of cardiac/vascular-like progenitors and is able to differentiate into cardiomyocytes in-vitro.

Results: Here, we demonstrated that the MUR-1 can reach the injured cells/tissue and make contacts with the damaged cardiomyocytes, likely through connexin 43, N-cadherin and von Willebrand Factor mediated cell-cell interactions, both in in-vitro and ex-vivo models. Furthermore, we found that SDF-1, FGF-2 and HGF, but not VEGF are involved as chemotactic factors in MUR-1 migration, notifying a similarity with neural crest cell behavior during the organogenesis of both the splancnocranium and the heart.

Conclusions: herein we found a similarity between what happens during the heart organogenesis and the early migration and homing of MUR-1 cells in ischemic models.

General significance: The comprehension of molecular aspects underlying the early phases of stem cell migration and interaction with damaged organ contributes to the future achievement of the coveted stem cell-mediated organ regeneration and function preservation in-vivo.

Highlights

- MUR-1 dental pulp stem cells migrate towards injured cardiomyocytes

- MUR-1 cells make contact with cardiomyocytes by means of Connexin 43 and $\mathrm{N}$-cadherin

- MUR-1 cells adhere to injured cardiomyocytes by means of von Willebrand Factor

- MUR-1 cells are responsive to SDF-1, FGF-2 and HGF but not VEGF chemotaxis 


\section{Introduction}

Adult stem and progenitor cells present throughout the body may replace dying cells and reconstitute injured tissues, thus preserving organs and whole organism homeostasis. However, they are generally unable to guarantee enough regeneration after severe damage. For instance, myocardial infarction results in a massive cardiomyocyte (CM) loss due to apoptosis and necrosis, which is followed by $\mathrm{CM}$ replacement with stiff non-contractile scar tissue frequently inducing ventricular remodeling and organ failure [1-4]. Since the injured mammalian adult heart has an intrinsic limited capability to regenerate myocardium several approaches have been proposed to prevent or treat heart failure. These include: (i) delivery of factors aimed at stimulating the repairing ability of resident cardiac stem cells; (ii) reprogramming non-muscle cells (e.g. fibroblasts) into CMs; (iii) identification, manipulation and implantation of stem or progenitor cells [5-7]. Although these strategies are promising, they do not achieve cardiac regeneration sufficient to restore function of a failing heart and are still far from replacing classical non-resolutive strategies (rational use of drugs and heart transplantation) [8].

Observation that mesenchymal stem cells (MSCs) of both homo- and hetero-topic origins can differentiate in-vitro towards cardiac lineage [6, 9-11] provoked increasing interest and perspective about the possibility to restore damaged myocardium with MSCs. Since cells "implanted in" or "delivered to" the target site may frequently vanish within few days, some Authors support the hypothesis that MSCs promote positive actions in terms of cardiac functionality due to production of trophic factors, induction of vasculogenesis, and differentiation into CM $[5,6]$. However, the extent of stem cell-induced myocardial repair has not yet been defined, as the preclinical results are controversial and the clinical experimentations are still in progress or almost limited to phase-I trials [6, 12-14]. In this point of view, local and systemic administrations of different MSCs hitherto resulted in poor improvement of cardiac function [6, 15].

The exegesis of these controversial results remains still unclear. Anyhow, molecular and biological data about MSC early homing in cardiac tissue are scarce or frequently absent; MSCs are reported to display a limited plasticity in the differentiation process towards a functional contractile phenotype [16]; finally, the heterogeneity in MSC derivation, antigen expression, together with the differences in isolation and expansion protocols, further contributed to complicate the comprehension and integration of the available data.

In this context, our group recently isolated, identified and characterized a MSC line from rat dental pulp (MUR-1), a tissue directly derived from the neural crest, and hence featuring peculiar characteristics [17]. This cell line can be propagated and passaged for long time in a feedlayer/supplement-free culture without any signs of neoplastic transformation and spontaneous differentiation or alterations in geno- and pheno-type, clonogenicity, self-renewal and potency. Invitro, MUR-1 cells were seen to differentiate (under appropriate stimulations) not only into adipogenic, osteogenic, chondrogenic lineages, but also toward neurogenic and cardiomyogenic lineages. Importantly, in the last case, MUR-1 cells demonstrated the appearance of a properly organized $\alpha$-sarcomeric actinin. Moreover, MUR-1 cells constitutively express markers typical of 
cardiac/vascular-like progenitors, such as c-Kit, Endoglin, Flk1, Nkx-2.5, Mef2c, Gata4, ADRB2, and CX43, together with several stemness markers typically depicting the undifferentiated mesenchymal or an even less differentiated/embryonic-like status (e.g. CD90, c-Myc, Oct4, SSEA1, Fragilis1, Stella and YAP1).

Based on the above findings, we hypothesized that MUR-1 might sense signals from injured CMs and migrate towards them. Therefore, the aim of the present study is to improve the knowledge on the potential early homing of dental pulp stem cells in infarcted hearts. Both in-vitro and exvivo model were used to assess the behavior of these cells and to identify the involved chemotactic factors. 


\section{Materials and methods}

\subsection{Cell culture and in-vitro damage assessment on cardiomyocytes}

MUR-1 rat dental pulp stem cell line was previously established [17] and stored in our laboratory. The embryo rat cardiomyocyte ( $\mathrm{H} 9 \mathrm{c} 2)$ cell line was a generous gift from Dr. Claudia Penna (University of Turin). Both cell lines were standardly cultured in $75 \mathrm{~cm}^{2}$ TPP ${ }^{\circledR}$ flasks (TPP Techno Plastic Products AG, Trasadingen, Switzerland) in RPMI-1640 medium (PAA Laboratories GmbH, Cölbe, Germany) supplemented with $10 \%$ fetal calf serum (FCS) (PAA Laboratories GmbH), 100 $\mathrm{U} / \mathrm{ml}$ penicillin $\mathrm{G}, 40 \mu \mathrm{g} / \mathrm{ml}$ gentamicin sulfate and $2,5 \mu \mathrm{g} / \mathrm{ml}$ amphotericin $\mathrm{B}$ at $37^{\circ} \mathrm{C}$ in a humidified $5 \% \mathrm{CO}_{2}$ atmosphere.

H9c2 cells were plated at the density of $5 \times 10^{4} /$ well in 96-well plates (Becton Dickinson Labware, BD Italia, Buccinasco, Milano, Italy). After one day, cells underwent one of the following injuring protocols: (i) 24h-lasting $1 \% \mathrm{O}_{2}$ hypoxia in an "Invivo $2-200$ " hypoxic chamber (Ruskinn Technology Ltd, Pencoed, UK); (ii) 24h-lasting serum deprivation; (iii) a combination of both [18]. Untreated H9c2 were used as control. H9c2 viability was assessed after the injury by 3-(4,5-Dimethylthiazol2-yl)-2,5-diphenyl-tetrazolium bromide (MTT) [19]. Briefly, MTT was added to growth medium (final concentration $0.5 \mathrm{mg} / \mathrm{ml}$ ) and cells were further cultured for $3 \mathrm{~h}$ in normal condition. Medium was then replaced with equal volume of dimethyl sulfoxide to lyse cells. The MTT absorbance was read at $560 \mathrm{~nm}$ with an Asys UVM-340 microplate reader (Biochrom, Cambridge Science Park, Cambridge, UK). MTT data were expressed as percentage of the control (standard culture condition). Experiments were performed in triplicate.

\subsection{MUR-1 migration assay}

MUR-1 migration ability was assessed in $8 \mu \mathrm{m}$ pore-sized transwell inserts (Boyden chambers, Becton Dickinson Labware, Franklin Lakes, NJ, USA). Briefly, H9c2 were plated in 24-well plates and damaged as describe above. At the end of injury induction, a transwell insert seeded with $8 \times 10^{4}$ MUR-1 cells was added to each H9c2 containing well. Migration was allowed for $24 \mathrm{~h}$ in serum-free normal-oxygen condition allowing H9c2 cells to release/secrete post-damage chemotactic factors. Medium additioned with $30 \%$ FBS was used as positive control of maximum migration potential, while serum-free medium was used as negative control [20]. After the $24 \mathrm{~h}$ incubation, transwell inserts were removed, gently washed and fixed in $2.5 \%$ glutaraldehyde. To quantify migration, transwell inserts were stained with crystal violet and four randomly chosen fields were photographed with an Eclipse TS100 microscope coupled with a DS-L1 camera control unit (Nikon Instruments S.p.A, Firenze, Italy). Color intensity was gathered with ImageJ software (http://imagej.nih.gov/ii). Migration ability was expressed as fold changes of negative control. Each experiment, consisting of two transwell inserts for each condition, was done in triplicate. 


\subsection{MUR-1 adhesion assay}

Adhesiveness of MUR-1 cells on H9c2 feeder was assessed as previously described [21] with some modifications. Sub-confluent MUR-1 were harvested with trypsin-EDTA solution (PAA Laboratories $\mathrm{GmbH})$, rinsed twice with phosphate buffer saline (PBS), and resuspended in a PBS solution containing $2.5 \mu \mathrm{M}$ carboxyfluorescein diacetate succinimidyl ester (CFDA-SE, Sigma-Aldrich) under continuous stirring for $15 \mathrm{~min}$. After labeling, cells were rinsed twice in PBS and resuspended in RPMI-1640 supplemented with 5\% FCS. Confluent H9c2 cells grown on 96-well plates (Becton Dickinson Labware) underwent 24h-lasting serum deprivation. Undamaged H9c2 cells were used as control. Before assay, injured and control H9c2 were rinsed once with Hank's balanced solution (HBSS) and left in $50 \mu$ l HBSS. Labeled MUR-1 at $1 \times 10^{4} / 50 \mu$ l density were added to H9c2 cells and incubated for $30 \mathrm{~min}$ at $37^{\circ} \mathrm{C}$ and $5 \% \mathrm{CO}_{2}$. After incubation, each well was washed twice with PBS, fixed in $4 \%$ paraformaldehyde and bound MUR-1 cells were imaged in fluorescence and counted. The same experiment was also performed in 8-well chamber-slides (Lab-Tek, Thermo Fischer Scientific Inc., Waltham, MA, USA) in order to assess the involvement of connexin-43 (CX43), Ncadherin (N-CAD) and von Willebrand factor (VWF) in MUR-1 adhesiveness. Slides were incubated with specific primary antibodies overnight at $4^{\circ} \mathrm{C}$ and then with appropriate secondary antibodies for $1 \mathrm{~h}$ at room temperature. The used antibodies and dilutions are reported in Table 1. Image acquisition of specific antigenic expression was carried out with a TCS SP5 confocal laser microscopy system (Leica Microsystem S.r.I., Milano, Italy). Each experiment was done in triplicate.

\subsection{Hearts isolation}

Hearts were isolated as previously described [22]. Briefly, 10 min after heparin injection (200 IU, i.m., Roche, Milan, Italy), five month-old Wistar rats (male, $n=15$, Harlan-Italy, San Pietro al Natisone, Italy) were anesthetized (ketamine $100 \mathrm{mg} / \mathrm{kg}$ and xylazine $5 \mathrm{mg} / \mathrm{kg}$ ) and sacrificed.The hearts were rapidly excised and placed in ice-cold Krebs-Henseleit (KH) buffer supplemented with $5 \mu \mathrm{g} / \mathrm{ml} 10 \mathrm{mg} / \mathrm{ml}$ xylocaine to prevent the appearance of arrhythmias. Then they were suspended to a Langendorff apparatus and retrogradely perfused via aorta at constant flow with $\mathrm{KH}$ buffer in a non-recirculating way. The perfusate buffer was saturated with $95 \% \mathrm{O}_{2}$ and $5 \% \mathrm{CO}_{2}$ gas mixture and infused at $37^{\circ} \mathrm{C}$. The coronary flow was adjusted with a constant flow perfusion pump (Watson-Marlow 505DU, Falmouth, Cornwall, UK) to obtain a level of $9 \mathrm{ml} / \mathrm{min} / \mathrm{g}$ corresponding to a perfusion pressure of about $80-85 \mathrm{mmHg}$ during the stabilization period.

\subsection{MUR-1 engraftment}

MUR-1 cells were engrafted following the protocol of Penna et al [23], with some modifications. Briefly, sub-confluent MUR-1 cells were harvested with $0.25 \%$ trypsin solution (Sigma-Aldrich) and added of complete medium. Cells were CDFA-SE-labeled as above described, resuspended in PBS at $1 \times 10^{6} / 300 \mu$ l density and implanted in the apex (area not interested by ischemia) of isolated hearts from both control $(\mathrm{Ctrl}, \mathrm{n}=7)$ and ischemia/reperfusion $(\mathrm{I} / \mathrm{R}, \mathrm{n}=8)$ groups. In Ctrl, MUR-1 
cells were injected after 55 min of stabilization. In I/R group, after 20 min of stabilization, the infarction was obtained by ligation of the left anterior descendent coronary artery proximally to the origin of the left circumflex artery. After $30 \mathrm{~min}$, the occlusion was removed and MUR-1 cells were implanted after $5 \mathrm{~min}$ of reperfusion. After the engraftment, hearts of both groups were perfused for $4 \mathrm{~h}$ and then removed from the Langendorff's apparatus.

Three hearts randomly chosen from each group were stained with trypan blue to assess extension of ischemic areas. Twenty $\mathrm{ml}$ of trypan blue 1:500 in PBS were infused into the aorta at $150 \mathrm{ml} / \mathrm{h}$ rate and then washed with an equal volume of PBS using a syringe pump (STC 31521 Terumo Inc., Tokyo, Japan). All the hearts were fixed in $4 \%$ paraformaldehyde and OCT (Tissue-Tek ${ }^{\circledR}$ O.C.T.Compound, Sakura Finetek Europe B.V., Zoeterwoude, Netherlands) embedded for the histological analyses.

\subsection{Histological analyses}

Ten micrometers thick sections were obtained cutting the whole heart starting from the apex. All sections were observed with LSM 510 laser confocal microscopy system (Zeiss, Jena, Germany) to study the early homing of the green CFDA-SE labeled MUR-1. For each heart, the volume of myocardium where MUR-1 cells migrated (volume of migration) was calculated as the sum of four different pyramidal frustum volumes. Briefly, it was obtained gathering the areas circumscribed by MUR-1 cells in 5 equidistant sections (ranging from the lowest to the highest section in which MUR-1 cells were detected) and applying the formula:

$\frac{1}{3} \sum_{i=1}^{4} h_{i}\left[B_{i}+B_{i+1}+\sqrt{B_{i} B_{i+1}}\right]$

where $B_{i}$ and $B_{i+1}$ represent the bottom and the top base area, respectively and $h_{i}$ represents the perpendicular height from the bottom to the top area which is calculated from the number of slices interposed between the two frustum bases.

Sections from each heart were stained for CX43, N-CAD and VWF, as described above.

\subsection{MUR-1 characterization for involved chemotactic receptor}

Expression of chemotactic factor receptors was assessed by immunocytochemical analyses. MUR1 cells were cultured on poly-D-lysine-coated coverslips and then stained as described above. The used antibodies and dilutions are reported in Table 1. Image acquisition of specific antigen expression was carried out with a TCS SP5 confocal laser microscopy system (Leica Microsystem S.r.I.).

The involvement of each chemotactic receptor in MUR-1 migration was assessed by means of Boyden chambers. Transwell inserts seeded with $8 \times 10^{4}$ MUR-1 cells were added to wells containing SDF-1 (50-1500 ng/ml), VEGF (1-500 ng/ml), FGF-2 (10-200 ng/ml) or HGF (20-500 $\mathrm{ng} / \mathrm{ml}$ ) in serum-free medium. All factors were kindly supplied by ImmunoTools, Friesoythe, Germany (see acknowledgments). After $24 \mathrm{~h}$, transwell inserts were processed and migrations 
quantified as described above. Each experiment, consisting of two transwell inserts for each condition, was done in triplicate.

\subsection{Statistical analysis}

Differences among cell viabilities were assessed with two-way ANOVA and Bonferroni post-test. One-way ANOVA and Newman-Keuls multiple comparison test (for post-ANOVA comparisons) were used to evaluate the statistical significance of the differences in cell migration in-vitro and ex-vivo. Two-tailed Student's t-test was used to evaluate MUR-1 adhesiveness on H9c2 cells. All data are graphicated as box plot and analyzed with GraphPad Prism version 5.00 (GraphPad Software, San Diego California USA, http://www.graphpad.com), with $\mathrm{P}<0.05$ as the significance cut off. 


\section{Results}

\subsection{Chemotactic action of injured H9c2 on MUR-1}

Similarly to what previously described by Bonavita et al [18], H9c2 cell viability was greatly hampered $(\mathrm{P}<0.001)$ by either serum deprivation $(42.97 \pm 9.51 \%)$ or oxygen reduction $(68.97 \pm 12.65 \%)$ with respect to standard culture condition $(100 \pm 15.72 \%)$. Serum deprivation had a higher impact on cell viability if compared with oxygen reduction $(P<0.001)$. In this context, the concomitant treatment with serum deprivation and oxygen reduction induced a slight worsening of $\mathrm{H} 9 \mathrm{c} 2$ cell viability $(35.46 \pm 3.16 \%)$ when compared to the serum-free condition alone $(P<0.05)$. MUR-1 migration ability toward H9c2 injured by serum deprivation either with or without hypoxia was assessed. After $24 \mathrm{~h}$ incubation, injured H9c2 were able to induce a 2-fold MUR-1 migration ability relative to the negative controls $(\mathrm{P}<0.001)$. In particular, the hypoxic condition induced a $15.94 \%$ increase in migration ability with respect to the normoxic one (2.33-fold vs 2.01 -fold, $P<0.01)$. In the positive control a 5 -fold migration ability was observed $(P<0.001$, Fig. $1 \mathrm{~A})$.

\subsection{Injured H9c2 cells enhance MUR-1 adhesion}

We assessed whether MUR-1 cells could adhere to H9c2 feeder and whether this adhesiveness could change in response to the starvation-mediated injury. MUR-1 cells adhered to H9c2 cells in both control and injuring conditions (Fig. 1B), but the H9c2 serum starvation induced an increment of adhesion (+81.7\%) with respect to the control (591.2 \pm 46.20 MUR-1/well vs $325.4 \pm 58.19$ MUR$1 /$ well, $P<0.01$ ). Since $C X 43, N-C A D$ and VWF are involved in cell adhesion $[21,24-28]$, we evaluated their localization on the MUR-1 (identifiable for their green labeling with CFDA-SE), which adhere to H9c2 cells. CX43 was found between MUR-1 and H9c2 in both control and injury conditions (Fig. 1C-D). Interestingly, MUR-1 appeared generally round-shaped in the former case and more elongated through the injured CMs in the latter. Similarly, N-CAD appeared expressed in both conditions (Fig. 1E-F). Unlike what observed for CX43 and N-CAD, vWF localization on MUR-1 was greatly affected by H9c2 serum starvation-mediated injury. In fact, while in the control vWF was predominantly confined into the H9c2 and MUR-1 cell cytoplasm (Fig. 1G), in the injured tissue it was mainly located on the membranes, suggesting an involvement in the setting-up of focal adhesion between MUR-1 and injured H9c2 cells (Fig. 1H).

\subsection{Behavior of MUR-1 cells in normal and infarcted hearts}

To confirm the tropism displayed by MUR-1 in response to chemotactic stimuli produced by injured CMs, their migration was tested in an ex-vivo ischemic heart model. CDFA-SE-labeled MUR1 cells were injected into the apex of the hearts. Indeed, at the histological observation MUR-1 appeared stained in bright-green, which allowed their recognition and localization within the myocardium.

In I/R hearts, MUR-1 cells greatly spread throughout the left ventricle tissue, whereas they formed clusters in the Ctrl (Fig. 2A-D). Furthermore, MUR-1 cells can be detected in $344 \pm 52$ and $227 \pm 19$ $10 \mu \mathrm{m}$-thickned serial slices in the $\mathrm{I} / \mathrm{R}$ and $\mathrm{Ctrl}$ hearts, respectively $(\mathrm{P}<0.001)$. Hence, great differences were present between the two groups in terms of MUR-1 migration: the migration 
volumes in 3-D reconstructed hearts were $18.04 \pm 11.45 \mathrm{~mm}^{3}$ and $3.04 \pm 0.88 \mathrm{~mm}^{3}$ in I/R and Ctrl, respectively $(\mathrm{P}<0.05$, Fig. $2 \mathrm{E}$ ). Moreover, the volume of MUR-1 migration corresponded to the extension of ischemic damage within tissues, as shown by the co-localization of MUR-1 cells with injured area highlighted by trypan blue staining (Fig. 2F-G).

\subsection{Immunohistochemical analysis of MUR-1 cell early homing in the cardiac tissue} As MUR-1 cells express CX43 [17], N-CAD and vWF which are involved in MUR-1 adhesiveness invitro (as described in the paragraph 3.2), their cellular localization was analyzed also after ex-vivo implantation. CX43 localization changed in response to ischemic condition. Indeed, in Ctrl hearts (Fig. 3A-B) it was mainly present amidst MUR-1 cells allowing clusters formation, while in I/R tissues (Fig. 3C-G), CX43 was present between the two histotypes allowing MUR-1 cells to keep contact with the host fibers. N-CAD seems to have a similar pattern of expression (Fig. $3 \mathrm{H}-J$ ); in fact CX43 and N-CAD are predominantly co-localized, although this phenomena appears more evident in I/R hearts than in the CTRL (Fig. 4). Finally, vWF was nearly absent in Ctrl hearts (Fig. 5AB) except for vessels (not shown), but it was detectable as spots in I/R tissues, where it mainly colocalized with MUR-1 cells (Fig. 5C-F).

3.5. Identification of the major chemotactic factors involved in MUR-1 migration To identify the stimuli involved in MUR-1 migration, we assessed the expression of membrane receptors specific for chemotactic factors and the migratory effects of the latter in a Boyden chamber assay.

Immunocytochemistry highlighted the presence of the SDF-1 receptor (CXCR4), fibroblast growth factor receptor 1 (FGFR1), hepatocyte growth factor receptor (c-MET) and vascular endothelial growth factor receptor 1 (Flt-1) (Fig. 6A) in MUR-1 cells.

When the migration of MUR-1 cells in response to soluble factors was analyzed in Boyden chambers, SDF-1 was found to induce migration only at $500 \mathrm{ng} / \mathrm{ml}$ (Fig. 6B1; P<0.05) and FGF-2 only at $50 \mathrm{ng} / \mathrm{ml}$ (Fig. 6B2; $\mathrm{P}<0.05$ ), respectively, but neither at lower nor higher concentrations. The level of migration was comparable for the two factors $(P=0.76)$. HGF stimulated migration at all evaluated concentrations in a dose-dependent relationship (Fig. 6B3; $\mathrm{P}<0.05$ ). A hundred $\mathrm{ng} / \mathrm{ml}$

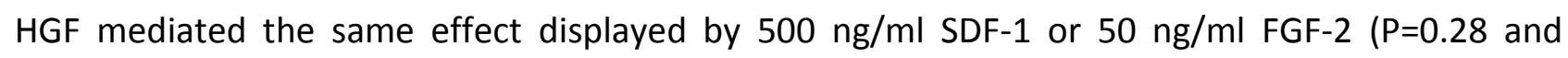
$\mathrm{P}=0.15$, respectively). At higher concentrations $(250$ and $500 \mathrm{ng} / \mathrm{ml}$ ) the migratory response was even higher $(P<0.001)$. On the contrary, VEGF did not induce migration in MUR-1 cells at any of the evaluated concentrations (Fig. 6B4). 


\section{Discussion}

Here we report that the MUR-1 dental pulp stem cells are attracted by injured CMs in both in-vitro and ex-vivo models. Thus, in an experimentally infarcted heart, they migrate to the injured myocardium from a remote (non-ischemic) site of injection. The in-vitro experiments suggested that MUR-1 migration depends on the expression on their membrane of functional receptors for different growth factors, namely SDF-1, FGF-2, and HGF, which are generally released by the injured myocardium [29-34].

Since ischemic injuries of the heart are characterized by the loss of contractile cells and so far there are not definitive pharmacological/procedural treatments $[2,8]$, the possibility of a cell based therapy aiming at replacing the apoptotic and necrotic CMs could greatly enhance both expectancy and quality of patients' life. Unfortunately, cell-therapy still lacks consistent results in clinical trials although sometimes promising ones have been obtained [6, 12-15, 35].

It is accepted that the heart contains some stem/progenitor cells, which are responsible for the maintenance of the organ homeostasis. Although recently some Authors demonstrated the presence of $\mathrm{c}^{-\mathrm{Kit}^{+}}$cardiac stem cells able to mediate cardiac regeneration and repair in rodents $[36,37]$, resident cardiac stem cells are insufficient or inadequate to repair a severely injured heart [38]. The possibility to recruit multipotent cells within the organism can thus be an option [6]. The present study was planned to unravel some still elusive and debated aspects of stem cell early homing in the heart after ischemic lesion. We employed the MUR-1 dental-pulp rat stem line due to its $\mathrm{c}-\mathrm{Kit}^{+} / \mathrm{Nkx}-2.5^{+} / \mathrm{Mef2c}^{+} / \mathrm{Gata4}^{+} / \mathrm{CX} 43^{+} / \mathrm{Flk1}^{+} /$Endoglin $^{+} / \mathrm{CD} 34^{-} / \mathrm{CD} 45^{-}$phenotypic profile [17] that is comparable to those of some cardiomyocyte progenitor cells $[39,40]$ and because of its capability (under appropriate stimuli) to differentiate into cardiomyocyte lineage in-vitro, as previously described [17] and here confirmed (data not shown). Furthermore, we considered that teeth (and more in general splanchnocranium structures) share a common neural crest origin with some parts of the heart [24, 41, 42]. In addition, here we demonstrated that MUR-1 cells constitutively express also N-CAD and VWF, two important factors for cardiac and vessel homeostasis and function $[28,43]$.

Our results showed that the H9c2 CM line, experimentally injured by hypoxia and/or serum deprivation [18], prompted MUR-1 cells migration. Furthermore, the serum starvation of H9c2 cells enhanced the MUR-1 adhesiveness, which seems to be based on CX43- and N-CAD-mediated intercellular interactions and vWF-mediated focal adhesions, as already reported for other cell types [21, 24-28]. Since motility and adhesiveness of MUR-1 cells were responsive to H9c2 cell injury in-vitro, we focused our attention on their homing in an ex-vivo model of ischemic rat heart. In this context, it was already shown that MSCs are able to remain in the infarcted area and make contact with the surrounding cardiac cells, if implanted within the injured tissues [23]. Yet, their ability to reach such sites after ischemia still remains unchecked. In the present study, we showed that dental pulp stem cells are able to migrate into damaged cardiac tissues leaving the site of injection, as evidenced by the co-localization of implanted cells and trypan blue stain. The dependence of this migration and the subsequent homing from the uninjured status of the myocardium was evinced by the scanty MUR-1 migration observed in the uninjured controls. 
Similarly to what occurred in-vitro, the homing of the migrated cells could be attributed to the organization of CX43 and N-CAD cell-cell interactions $[24,27,28]$ and to the vWF-mediated adhesion [21, 25] via p38 MAPK [26]. Interestingly, our data show that all considered factors are differently localized and organized if MUR-1 cells are implanted in control or infarcted hearts. In Ctrl hearts, CX43 and N-CAD were mainly detected amidst MUR-1 cells, which remained close to each other in the injection site, thus allowing the formation of local cell clusters. On the contrary, in I/R hearts, both were found pinpointed between MUR-1 cells and CMs. In this case, MUR-1 cells did not remain clusterized in the injection site but disaggregated and migrated. In addition, CX43 and N-CAD were generally co-localized on plasma membrane, in accord with the previous observation that presence of N-CAD is required for the proper assembly of CX43[28, 44, 45]. Although CX43 and N-CAD are involved in many cellular processes, including migration, their concomitant presence and localization between MUR-1 and CMs suggest the presence of both gap (electrical) and adherence (mechanical) junctions. Furthermore, the enhanced presence of vWF in ischemic tissues $[46,47]$ could mediate the permanence of migrated stem cells in the damaged area, as evinced by the localization of MUR-1 cells which were found onto or surrounded by vWF spots in I/R, but not in Ctrl hearts.

Using Boyden chamber assay, we identified the possible chemotactic factors involved in MUR-1 migration. It is known that SDF-1, FGF-2, HGF and VEGF are transiently released [29-34] after ischemia in order to mediate salvage and/or revascularization. We demonstrated that MUR-1 cells express the cognate receptors for SDF-1 (CXCR4), FGF-2 (FGFR1), HGF (c-MET) and VEGF (FIt-1, besides Flk-1 whose expression was previously reported [17]). MUR-1 motility depends in-vitro on SDF-1, FGF-2 and HGF, mimicking what occurs for neural crest cell migration during the heart organogenesis [24]. Indeed, the expressions of both FGF-2 and HGF are needed to promote gastrulation $[48,49]$ as well as to drive migration of cells from the neural crest $[48,50]$. At this stage, FGF-2 mainly induces these cells to migrate towards the mandibular mesenchymal regions [50] thus triggering the organogenesis of cranial tissues from which MUR-1 were isolated [17]. The expression of FGF-8 regulates the FGF-2 localization [50] and distance-dependent gene expression patterning in migrating neural crest cells: the farthest and most caudal become the cardiac ones [24]. Conversely, VEGF can attract neural crest cells to the hyoid arch [51], but it does not further induce cardiac neural crest cell migration from the circumpharyngeal ridge [24]. Likewise it also appears not involved in MUR-1 cell migration. Finally, HGF mediates the premyocardium formation through the condensation of cardiac neural crest cells, and later it contributes to drive the whole early heart development [52], whilst SDF-1 induces their condensation around the aortic arch arteries [24], whose proper development is regulated by FGF-2 [30,53]. Both HGF and SDF-1 expressions are needed to promote the cell commitment towards CM lineage via the induction of Gata4 and Mef2c transcription factors [54,55], already expressed by MUR-1 cells [17]. At the same time, FGF-2 regulates myocytes proliferation and epicardial cell development [30]. After mesenchyme-epithelium transition epicardial-derived cells migrate into the myocardium, and here they stop probably in response to hypoxia-mediated Flt-1 stimulation [56]. In myocardium they differentiate into smooth muscle cells and cardiac fibroblasts [57], thus contributing to originate atrio-ventricular valves and coronary arteries [58, 59]. 
In conclusion, herein we found a similarity between what happens during the heart organogenesis and the early migration and homing of MUR-1 cells in ischemic models. Indeed, MUR-1 migrated towards and within the lesion sites following SDF-1, FGF-2 and HGF signaling and made contact with CMs via CX43 and N-CAD, mimicking the cardiac neural crest cell behavior when they assemble in the developing embryo [24, 28, 60]. Although we did not evaluated the MUR-1 homing and fate in-vivo (in terms of survival or spontaneous differentiation toward CM and/or endothelial lineages), our results seem to be consistent with the in-vivo experiments of Gandia and co-workers [61] in which dental pulp stem cells are able to improve cardiac function and reduce infarct size one month after the ischemic occurrence, even if they were transplanted into the ischemia border zone. Moreover, the MUR-1 cell behavior and cardiac homing could be attributed to their high positivity to c-Kit [17] as demonstrated by Ellison et al [36], who recently described the key-rule of c-Kit ${ }^{+}$cardiac stem cells in the heart repair and regeneration.

Although the problem concerning the most suitable stem/progenitor cells for heart repair is still open, we used MUR-1 cells not to propose a clinical application, but rather to bring some lights on the initial and possibly decisive contact between stem cells and injured tissues. In our opinion, these results could represent the first of many steps required to achieve the coveted stem cellmediated organ regeneration and function preservation in-vivo.

\section{Disclosure}

None declared

\section{Acknowledgements}

This work was supported by local grant (ex 60\%) of the University of Turin and private grants generously funded by "AMF s.n.c.", in the persons of Cinzia Pagliero and Mario Furlanetto, and "Roda Forge S.p.A.", in the person of Donato Manieri. All cytokines utilized in this paper are from ImmunoTools, Friesoythe, Germany, as a Prize to FDS as a Winner of "ImmunoTools Award 2013". Special thanks to Pasquale Pagliaro and Giancarlo Forte who graciously offered to discuss the manuscript and Susanna Antoniotti and Mauro Papotti who gently provided some antibodies. In addition, we would like to thank Claudio Rullent for his mathematical assistance. 


\section{Bibliography}

[1] P. Anversa, J. Kajstura, G. Olivetti, Myocyte death in heart failure, Curr Opin Cardiol, 11 (1996) 245-251.

[2] J.J. Gajarsa, R.A. Kloner, Left ventricular remodeling in the post-infarction heart: a review of cellular, molecular mechanisms, and therapeutic modalities., Heart Fail Rev, 16 (2011) 13-21.

[3] B.I. Jugdutt, Remodeling of the myocardium and potential targets in the collagen degradation and synthesis pathways., Curr Drug Targets Cardiovasc Haematol Disord, 3 (2003) 1-30.

[4] B.I. Jugdutt, Ventricular remodeling after infarction and the extracellular collagen matrix: when is enough enough?, Circulation, 108 (2003) 1395-1403.

[5] G. Forte, S. Pagliari, F. Pagliari, M. Ebara, P. Di Nardo, T. Aoyagi, Towards the Generation of PatientSpecific Patches for Cardiac Repair, Stem Cell Rev, 9 (2013) 313-325.

[6] J. Liu, Z. Zhang, Y. Liu, C. Guo, Y. Gong, S. Yang, M. Ma, Z. Li, W.Q. Gao, Z. He, Generation, characterization, and potential therapeutic applications of cardiomyocytes from various stem cells, Stem Cells Dev, 21 (2012) 2095-2110.

[7] E. Willems, M. Lanier, E. Forte, F. Lo, J. Cashman, M. Mercola, A chemical biology approach to myocardial regeneration, J Cardiovasc Transl Res, 3 (2011) 340-350.

[8] P.Z. Gerczuk, R.A. Kloner, An update on cardioprotection: a review of the latest adjunctive therapies to limit myocardial infarction size in clinical trials., Journal of the American College of Cardiology, 59 (2012) 969-978.

[9] J. Leor, Y. Amsalem, S. Cohen, Cells, scaffolds, and molecules for myocardial tissue engineering, Pharmacol Ther, 105 (2005) 151-163.

[10] G. Forte, S. Pietronave, G. Nardone, A. Zamperone, E. Magnani, S. Pagliari, F. Pagliari, C. Giacinti, C. Nicoletti, A. Musaró, M. Rinaldi, M. Ribezzo, C. Comoglio, E. Traversa, T. Okano, M. Minieri, M. Prat, P. Di Nardo, Human cardiac progenitor cell grafts as unrestricted source of supernumerary cardiac cells in healthy murine hearts, Stem Cells, 29 (2011) 2051-2061.

[11] A. Zamperone, S. Pietronave, S. Merlin, D. Colangelo, G. Ranaldo, E. Medico, F. Di Scipio, G.N. Berta, A. Follenzi, M. Prat, Isolation and Characterization of a Spontaneously Immortalized Multipotent Mesenchymal Cell Line Derived from Mouse Subcutaneous Adipose Tissue, Stem Cells Dev, 22 (2013) 28732884.

[12] R. Bolli, A.R. Chugh, D. D'Amario, J.H. Loughran, M.F. Stoddard, S. Ikram, G.M. Beache, S.G. Wagner, A. Leri, T. Hosoda, F. Sanada, J.B. Elmore, P. Goichberg, D. Cappetta, N.K. Solankhi, I. Fahsah, D.G. Rokosh, M.S. Slaughter, J. Kajstura, P. Anversa, Cardiac stem cells in patients with ischaemic cardiomyopathy (SCIPIO): initial results of a randomised phase 1 trial, Lancet, 378 (2011) 1847-1857.

[13] E. Forte, I. Chimenti, L. Barile, R. Gaetani, F. Angelini, V. Ionta, E. Messina, A. Giacomello, Cardiac cell therapy: the next (re)generation, Stem Cell Rev, 7 (2011) 1018-1030.

[14] A.R. Williams, J.M. Hare, Mesenchymal stem cells: biology, pathophysiology, translational findings, and therapeutic implications for cardiac disease, Circ Res, 109 (2011) 923-940.

[15] D.K. Singla, Stem cells in the infarcted heart., J Cardiovasc Transl Res, 3 (2010) 73-78.

[16] M.P. Gallo, R. Ramella, G. Alloatti, C. Penna, P. Pagliaro, A. Marcantoni, F. Bonafé, G. Losano, R. Levi, Limited plasticity of mesenchymal stem cells cocultured with adult cardiomyocytes, J Cell Biochem, 100 (2007) 86-99.

[17] A.E. Sprio, F. Di Scipio, S. Raimondo, P. Salamone, F. Pagliari, S. Pagliari, A. Folino, G. Forte, S. Geuna, P. Di Nardo, G.N. Berta, Self-Renewal and Multipotency Coexist in a Long-Term Cultured Adult Rat Dental Pulp Stem Cell Line: An Exception to the Rule?, Stem Cells Dev, 21 (2012) 3278-3288.

[18] F. Bonavita, C. Stefanelli, E. Giordano, M. Columbaro, A. Facchini, F. Bonafè, C.M. Caldarera, C. Guarnieri, $\mathrm{H} 9 \mathrm{c} 2$ cardiac myoblasts undergo apoptosis in a model of ischemia consisting of serum deprivation and hypoxia: inhibition by PMA, FEBS Lett, 536 (2003) 85-91.

[19] G.N. Berta, P. Salamone, A.E. Sprio, F. Di Scipio, L.M. Marinos, S. Sapino, M.E. Carlotti, R. Cavalli, F. Di Carlo, Chemoprevention of 7,12-dimethylbenz[a]anthracene (DMBA)-induced oral carcinogenesis in hamster cheek pouch by topical application of resveratrol complexed with 2-hydroxypropyl-betacyclodextrin, Oral Oncol, 46 (2010) 42-48. 
[20] A.L. Ponte, E. Marais, N. Gallay, A. Langonné, B. Delorme, O. Hérault, P. Charbord, J. Domenech, The in vitro migration capacity of human bone marrow mesenchymal stem cells: comparison of chemokine and growth factor chemotactic activities, Stem Cells, 25 (2007) 1737-1745.

[21] I.A. Potapova, I.S. Cohen, S.V. Doronin, Apoptotic endothelial cells demonstrate increased adhesiveness for human mesenchymal stem cells, J Cell Physiol, 219 (2009) 23-30.

[22] R. Rastaldo, S. Cappello, A. Folino, G.N. Berta, A.E. Sprio, G. Losano, M. Samaja, P. Pagliaro, Apelin-13 limits infarct size and improves cardiac postischemic mechanical recovery only if given after ischemia, Am J Physiol Heart Circ Physiol, 300 (2011) H2308-H2315.

[23] C. Penna, S. Raimondo, G. Ronchi, R. Rastaldo, D. Mancardi, S. Cappello, G. Losano, S. Geuna, P. Pagliaro, Early homing of adult mesenchymal stem cells in normal and infarcted isolated beating hearts., $J$ Cell Mol Med, 12 (2008) 507-521.

[24] M.L. Kirby, M.R. Hutson, Factors controlling cardiac neural crest cell migration, Cell Adh Migr, 4 (2010) 609-621.

[25] M. Morganti, A. Carpi, B. Amo-Takyi, A. Sagripanti, A. Nicolini, R. Giardino, C. Mittermayer, Von Willebrand's factor mediates the adherence of human tumoral cells to human endothelial cells and ticlopidine interferes with this effect, Biomedicine \& pharmacotherapy = Biomedecine \& pharmacotherapie, 54 (2000) 431-436.

[26] I.A. Potapova, I.S. Cohen, S.V. Doronin, Von willebrand factor increases endothelial cell adhesiveness for human mesenchymal stem cells by activating p38 mitogen-activated protein kinase, Stem cell research \& therapy, 1 (2010) 35.

[27] J.Y. Kresh, A. Chopra, Intercellular and extracellular mechanotransduction in cardiac myocytes, Pflugers Archiv : European journal of physiology, 462 (2011) 75-87.

[28] G.L. Radice, N-cadherin-mediated adhesion and signaling from development to disease: lessons from mice, Progress in molecular biology and translational science, 116 (2013) 263-289.

[29] A.T. Askari, S. Unzek, Z.B. Popovic, C.K. Goldman, F. Forudi, M. Kiedrowski, A. Rovner, S.G. Ellis, J.D. Thomas, P.E. DiCorleto, E.J. Topol, M.S. Penn, Effect of stromal-cell-derived factor 1 on stem-cell homing and tissue regeneration in ischaemic cardiomyopathy., Lancet, 362 (2003) 697-703.

[30] S. Liao, J. Bodmer, D. Pietras, M. Azhar, T. Doetschman, J. Schultz Jel, Biological functions of the low and high molecular weight protein isoforms of fibroblast growth factor-2 in cardiovascular development and disease, Dev Dyn, 238 (2009) 249-264.

[31] S.Q. Liu, B.J. Tefft, D. Zhang, D. Roberts, D.J. Schuster, A. Wu, Cardioprotective mechanisms activated in response to myocardial ischemia, Mol Cell Biomech, 8 (2011) 319-338.

[32] T. Nakamura, S. Mizuno, K. Matsumoto, Y. Sawa, H. Matsuda, T. Nakamura, Myocardial protection from ischemia/reperfusion injury by endogenous and exogenous HGF, J Clin Invest, 106 (2000) 1511-1519.

[33] N.G. Frangogiannis, C.W. Smith, M.L. Entman, The inflammatory response in myocardial infarction, Cardiovascular research, 53 (2002) 31-47.

[34] K. Pillarisetti, S.K. Gupta, Cloning and relative expression analysis of rat stromal cell derived factor-1 (SDF-1)1: SDF-1 alpha mRNA is selectively induced in rat model of myocardial infarction, Inflammation, 25 (2001) 293-300.

[35] G.M. Ellison, B. Nadal-Ginard, D. Torella, Optimizing cardiac repair and regeneration through activation of the endogenous cardiac stem cell compartment, J Cardiovasc Transl Res, 5 (2012) 667-677.

[36] G.M. Ellison, C. Vicinanza, A.J. Smith, I. Aquila, A. Leone, C.D. Waring, B.J. Henning, G.G. Stirparo, R. Papait, M. Scarfò, V. Agosti, G. Viglietto, G. Condorelli, C. Indolfi, S. Ottolenghi, D. Torella, B. Nadal-Ginard, Adult c-kitpos Cardiac Stem Cells Are Necessary and Sufficient for Functional Cardiac Regeneration and Repair, Cell, 154 (2013) 827-842.

[37] F.L. Xiang, X. Lu, Y. Liu, Q. Feng, Cardiomyocyte-specific overexpression of human stem cell factor protects against myocardial ischemia and reperfusion injury, Int J Cardiol, 168 (2013) 3486-3494.

[38] B.C. Jensen, C. Patterson, Heart Factory or Fiction? Cardiac Progenitor Cells and Regeneration, Circulation, (2013).

[39] M.J. Goumans, T.P. de Boer, A.M. Smits, L.W. van Laake, P. van Vliet, C.H. Metz, T.H. Korfage, K.P. Kats, R. Hochstenbach, G. Pasterkamp, M.C. Verhaar, M.A. van der Heyden, D. de Kleijn, C.L. Mummery, T.A. van Veen, J.P. Sluijter, P.A. Doevendans, TGF-beta1 induces efficient differentiation of human cardiomyocyte progenitor cells into functional cardiomyocytes in vitro, Stem cell research, 1 (2007) 138-149. 
[40] S.J. Kattman, E.D. Adler, G.M. Keller, Specification of multipotential cardiovascular progenitor cells during embryonic stem cell differentiation and embryonic development, Trends Cardiovasc Med, 17 (2007) 240-246.

[41] Y. Chai, X. Jiang, Y. Ito, P. Bringas, Jr., J. Han, D.H. Rowitch, P. Soriano, A.P. McMahon, H.M. Sucov, Fate of the mammalian cranial neural crest during tooth and mandibular morphogenesis, Development, 127

(2000) 1671-1679.

[42] T. Nakamura, M.C. Colbert, J. Robbins, Neural crest cells retain multipotential characteristics in the developing valves and label the cardiac conduction system, Circ Res, 98 (2006) 1547-1554.

[43] J.E. Sadler, Biochemistry and genetics of von Willebrand factor, Annual review of biochemistry, 67 (1998) 395-424.

[44] C.J. Wei, R. Francis, X. Xu, C.W. Lo, Connexin43 associated with an N-cadherin-containing multiprotein complex is required for gap junction formation in NIH3T3 cells, The Journal of biological chemistry, 280 (2005) 19925-19936.

[45] N.J. Severs, A.F. Bruce, E. Dupont, S. Rothery, Remodelling of gap junctions and connexin expression in diseased myocardium, Cardiovascular research, 80 (2008) 9-19.

[46] J.F. Dong, J.L. Moake, L. Nolasco, A. Bernardo, W. Arceneaux, C.N. Shrimpton, A.J. Schade, L.V. McIntire, K. Fujikawa, J.A. López, ADAMTS-13 rapidly cleaves newly secreted ultralarge von Willebrand factor multimers on the endothelial surface under flowing conditions, Blood, 100 (2002) 4033-4039. [47] C. Gandhi, D.G. Motto, M. Jensen, S.R. Lentz, A.K. Chauhan, ADAMTS13 deficiency exacerbates VWFdependent acute myocardial ischemia/reperfusion injury in mice, Blood, 120 (2012) 5224-5230.

[48] E. Andermarcher, M.A. Surani, E. Gherardi, Co-expression of the HGF/SF and c-met genes during early mouse embryogenesis precedes reciprocal expression in adjacent tissues during organogenesis, Dev Genet, 18 (1996) 254-266.

[49] R.T. Böttcher, C. Niehrs, Fibroblast growth factor signaling during early vertebrate development, Endocr Rev, 26 (2005) 63-77.

[50] Y. Kubota, K. Ito, Chemotactic migration of mesencephalic neural crest cells in the mouse, Dev Dyn, 217 (2000) 170-179.

[51] R. McLennan, J.M. Teddy, J.C. Kasemeier-Kulesa, M.H. Romine, P.M. Kulesa, Vascular endothelial growth factor (VEGF) regulates cranial neural crest migration in vivo, Dev Biol, 339 (2010) 114-125.

[52] D.A. Rappolee, A. Iyer, Y. Patel, Hepatocyte growth factor and its receptor are expressed in cardiac myocytes during early cardiogenesis, Circ Res, 78 (1996) 1028-1036.

[53] P. Spirito, Y.M. Fu, Z.X. Yu, S.E. Epstein, W. Casscells, Immunohistochemical localization of basic and acidic fibroblast growth factors in the developing rat heart, Circulation, 84 (1991) 322-332.

[54] C. Roggia, C. Ukena, M. Böhm, H. Kilter, Hepatocyte growth factor (HGF) enhances cardiac commitment of differentiating embryonic stem cells by activating PI3 kinase, Exp Cell Res, 313 (2007) 921930.

[55] A. Chiriac, A. Terzic, S. Park, Y. Ikeda, R. Faustino, T.J. Nelson, SDF-1-enhanced cardiogenesis requires CXCR4 induction in pluripotent stem cells, J Cardiovasc Transl Res, 3 (2010) 674-682.

[56] J. Tao, Y. Doughman, K. Yang, D. Ramirez-Bergeron, M. Watanabe, Epicardial HIF signaling regulates vascular precursor cell invasion into the myocardium, Dev Biol, 376 (2013) 136-149.

[57] H.E. Olivey, L.A. Compton, J.V. Barnett, Coronary vessel development: the epicardium delivers, Trends Cardiovasc Med, 14 (2004) 247-251.

[58] H. Lie-Venema, N.M. van den Akker, N.A. Bax, E.M. Winter, S. Maas, T. Kekarainen, R.C. Hoeben, M.C. deRuiter, R.E. Poelmann, A.C. Gittenberger-de Groot, Origin, fate, and function of epicardium-derived cells (EPDCS) in normal and abnormal cardiac development, ScientificWorldJournal, 12 (2007) 1777-1798.

[59] K.J. Lavine, D.M. Ornitz, Fibroblast growth factors and Hedgehogs: at the heart of the epicardial signaling center, Trends Genet, 24 (2008) 33-40.

[60] C.D. Rogers, A. Saxena, M.E. Bronner, Sip1 mediates an E-cadherin-to-N-cadherin switch during cranial neural crest EMT, The Journal of cell biology, 203 (2013) 835-847.

[61] C. Gandia, A. Armiñan, J.M. García-Verdugo, E. Lledó, A. Ruiz, M.D. Miñana, J. Sanchez-Torrijos, R. Payá, V. Mirabet, F. Carbonell-Uberos, M. Llop, J.A. Montero, P. Sepúlveda, Human dental pulp stem cells improve left ventricular function, induce angiogenesis, and reduce infarct size in rats with acute myocardial infarction, Stem Cells, 26 (2008) 638-645. 
Fig 1. In-vitro migration and adhesion induction of injured H9c2 feeder on MUR-1. (A) H9c2 cells cultured in hypoxic and/or serum-free conditions in the bottom compartment of Boyden chambers induce the migration of MUR-1 cells seeded in the top compartment. Negative and positive controls were serum-free and $30 \%$ FBS-supplemented medium, respectively. ( $\mathrm{N}=6$, each). (B) Injured H9c2 cells enhance MUR-1 adhesion. ( $N=48$, each). The involvement of (C-D) CX43 and (E-F) N-CAD (red) in MUR-1 cells (green) adhesiveness is evident for both (C and E) control and (D and F) injured H9c2 cells. (G-H) On the contrary, vWF (red) appears predominantly localized in the cytoplasm of MUR-1 in (G) controls, while it appears concurring to the establishment of focal adhesion on $(\mathrm{H})$ injured $\mathrm{H} 9 \mathrm{c} 2$ cells. Images are representative of $\mathrm{N}=6$ slides. In the box plot graphs, the lower and upper bars point the distance from the $10^{\text {th }}$ to $90^{\text {th }}$ percentile from the median, while the boxes range through the $25^{\text {th }}$ to $75^{\text {th }}$ percentile from the median. Inside the boxes, horizontal line indicates the median while "+" represents the mean. ${ }^{* *}=\mathrm{P}<0.01 ; * * *=\mathrm{P}<0.001$. Nuclei are counterstained with DAPI (blue). Scale bar $=25 \mu \mathrm{m}$.

Fig 2. Behavior of implanted MUR-1 cells differs between healthy and ischemic isolated hearts. Organ sections were reconstructed from (A) control and $(B)$ ischemic hearts. Perimeters delineate the migration areas. At higher magnification green-labeled MUR-1 appeared in clusters in (C) control group, while they are spread in (D) the ischemic hearts. The situation is further confirmed by differences between the two groups in terms of (E) MUR-1 migration volume. Moreover, (F-G) migrating MUR-1 co-localized in ischemic hearts with damaged tissues, which are stained with the red-fluorescent trypan blue dye. In box plot graph, "Ctrl" and "I/R" indicate the control and the ischemia/reperfusion group, respectively; the lower and upper bars point the distance from the $10^{\text {th }}$ to $90^{\text {th }}$ percentile from the median, while the boxes range through the $25^{\text {th }}$ to $75^{\text {th }}$ percentile from the median. Inside the boxes, horizontal line indicates the median while " + " represents the mean. ${ }^{*}=\mathrm{P}<0.05$. Scale bar: $\mathrm{A}-\mathrm{B}=1 \mathrm{~mm} ; \mathrm{C}-\mathrm{D}-\mathrm{F}=100 \mu \mathrm{m} ; \mathrm{G}=50 \mu \mathrm{m}$. Images are representative of sections from $\mathrm{N}=7$ control and $\mathrm{N}=8$ ischemic hearts. Trypan blue stained images are representative of sections from $\mathrm{N}=3$ ischemic hearts.

Fig 3. Ischemia affects Connexin 43 and N-cadherin localizations on implanted MUR-1 cells. (A-B) In Control hearts, CX43 (red) predominantly localizes amidst MUR-1 cells (green) with none or very few junctions with the heart fibers. On the contrary, (C-E) in infarcted hearts CX43 is pinpointed between tissues and single MUR-1 cells, which are infiltrating the fibers: (F-G) although not always present, CX43 positive spots can be appreciated in a series of adjacent slices as shown in the panel $\mathrm{G}$ (arrow). (H-J) The same pattern of expression appear also evident for N-CAD (red), in both (H) Ctrl and (I-J) I/R hearts (as evidenced by arrows). Nuclei are counterstained with DAPI (blue). Scale bar: $A$ and $C=50 \mu \mathrm{m} ; \mathrm{B}, \mathrm{D}-\mathrm{J}=10 \mu \mathrm{m}$. Images are representative of sections from $\mathrm{N}=7$ control and $\mathrm{N}=5$ ischemic hearts. 
Fig 4. Connexin 43 and $\mathrm{N}$-cadherin co-localization in normal and ischemic isolated hearts. Implanted MUR-1 cells (green) displayed a predominantly co-localization of both CX-43 (red) and $\mathrm{N}-\mathrm{CAD}$ (blue) along their membranes. (A) In Ctrl specimens, CX-43 is prevalently expressed amid MUR-1 cells, meanwhile N-CAD can be found also near host fivers. (B) Otherwise, in I/R hearts CX43 and N-CAD strictly co-localize to form junction between MUR-1 and injured cardiomyocytes. Scale bar $=10 \mu \mathrm{m}$. Images are representative of sections from $\mathrm{N}=7$ control and $\mathrm{N}=5$ ischemic hearts.

Fig 5. Ischemia affects von Willebrand Factor expression on implanted MUR-1 cells. In the ex-vivo model, (A-B) VWF (red) is not detectable in control group between MUR-1 (green) and heart tissues. On the contrary, it becomes evident (C-F) in injured tissues where it can co-localize with MUR-1 cells: by Z-stack analysis it is possible to highlight the superimposition of a (E) MUR-1 cell onto (F) vWF spots. Nuclei are counterstained with DAPI (blue). Scale bar: A $=25 \mu \mathrm{m} ; \mathrm{B}-\mathrm{G}=10 \mu \mathrm{m}$. Images are representative of sections from $\mathrm{N}=7$ control and $\mathrm{N}=5$ ischemic hearts.

Fig 6. MUR-1 characterization for chemotactic factor receptors expression and their activity. (A) MUR-1 cells express chemotactic factor receptors involved in heart organogenesis and diseases. CXCR4, C-X-C chemokine receptor type 4; FGFR1, Fibroblast Growth Factor Receptor 1; c-MET or HGFR, Hepatocyte Growth Factor Receptor; Flt-1 or VEGFR1, Vascular Endothelial Growth Factor Receptor 1. Nuclei are blue-stained, whereas receptor expression is highlighted in green. Scale bar: 1 -column $=75 \mu \mathrm{m} ; 2$-column $=25 \mu \mathrm{m}$. Images are representative of $\mathrm{N}=6$ slides. $(\mathrm{B})$ Migration of MUR-1 cells seeded in the top compartment of Boyden chambers after $24 \mathrm{~h}$ incubation with chemotactic factors ( 1 , SDF-1; 2, FGF-2; 3, HGF; 4, VEGF) at different concentrations in serum-free medium in the bottom compartment. Negative and positive controls were serum-free medium and $30 \%$ FBS-supplemented medium, respectively. In the box plot graphs, the lower and upper bars point the distance from the $10^{\text {th }}$ to $90^{\text {th }}$ percentile from the median, while the boxes range through the $25^{\text {th }}$ to $75^{\text {th }}$ percentile from the median. Inside the boxes, horizontal line indicates the median while " + " represents the mean. ${ }^{*}=\mathrm{P}<0.05 ;{ }^{* *}=\mathrm{P}<0.01 ;{ }^{* * *}=\mathrm{P}<0.001$. 
Table 1. Antibodies employed for immunocytochemistry analysis

\begin{tabular}{llll}
\hline Primary Ab (clone) & Host & Dilution & Supplier \\
\hline CX43 (C6219) & Rabbit & $1: 200$ & Sigma-Aldrich \\
N-CAD (3B9) & Mouse & $1: 100$ & Invitrogen \\
vWF (F3520) & Rabbit & $1: 400$ & Sigma-Aldrich \\
CXCR4 (ab2074) & Rabbit & $1: 400$ & Abcam \\
FGFR1 (V) & Rabbit & $1: 100$ & SantaCruz Biotechnology \\
C-MET (NO-23) & Mouse & $1: 1000$ & M. Prat* \\
Flt-1 (C-17)-G & Goat & $1: 100$ & SantaCruz Biotechnology \\
\hline Secondary Ab & Reactivity & Dilution & Supplier \\
\hline CY3-conjugate & Mouse & $1: 1000$ & Sigma-Aldrich \\
CY3-conjugate & Rabbit & $1: 1000$ & Sigma-Aldrich \\
Alexa Fluor 488 & Mouse & $1: 300$ & Molecular Probes \\
Alexa Fluor 488 & Rabbit & $1: 400$ & Molecular Probes \\
Alexa Fluor 488 & Goat & $1: 400$ & Molecular Probes \\
Biotin-SP-AffiniPure & Mouse & $1: 100$ & Jackson ImmunoResearch \\
\hline Tertiary Ab & Reactivity & Dilution & Supplier \\
\hline DyLight 405 & Streptavidin & $1: 100$ & Molecular Probes \\
\hline
\end{tabular}

* Patented: Prat, MG (2004) "Anti-HGF-r antibodies and their use" Pub.No. WO2004108766 A2. Abbreviations: CXCR4, fusin or SDF-1 receptor; FGFR1, fibroblast growth factor receptor 1; c-MET, hepatocyte growth factor receptor; Flt-1, vascular endothelial growth factor (VEGFR) -1; Flk-1, VEGFR-2;

CX43, Connexin 43; N-CAD, N-cadherin; vWF, Von Willebrand factor. 
A

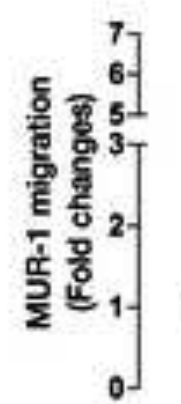

\begin{tabular}{c|cc|cl} 
& & & & \\
\cline { 1 - 5 } & $0 \%$ & $0 \%$ & $30 \%$ & FBS \\
\cline { 1 - 4 } $21 \%$ & $21 \%$ & $1 \%$ & $21 \%$ & $\mathrm{O}_{2}$ \\
- & H9c2 & H9c2 & - & Feeder
\end{tabular}

B

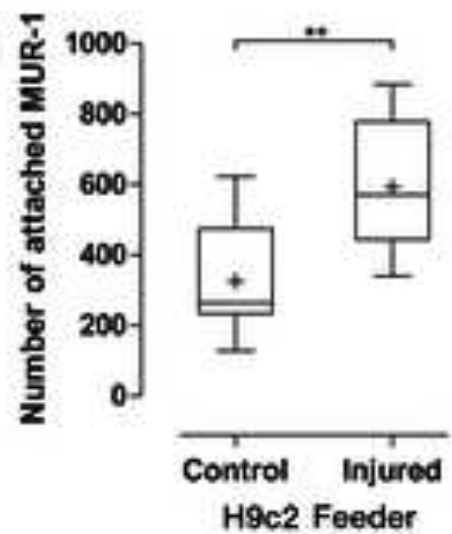

C

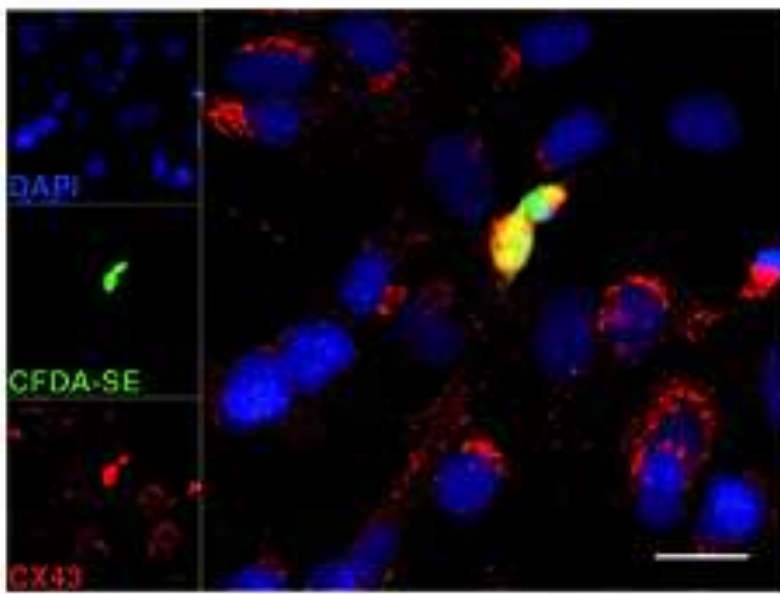

E

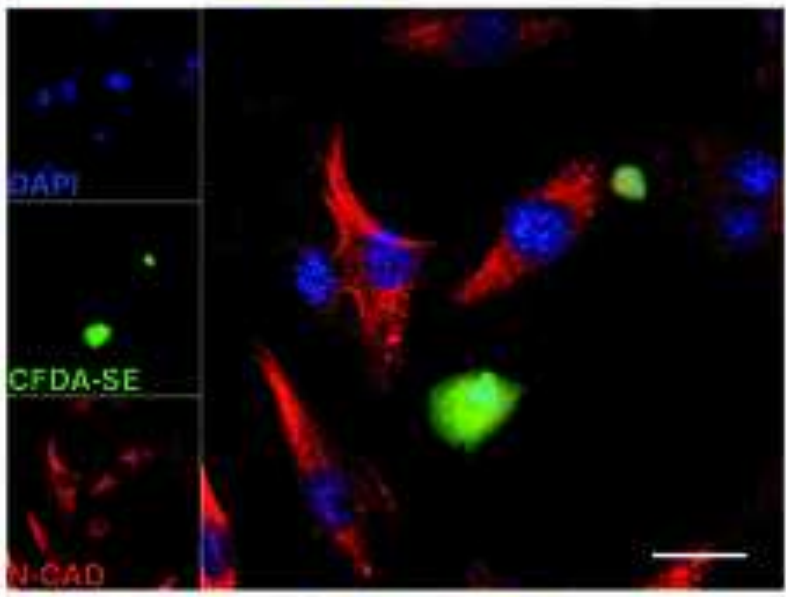

G

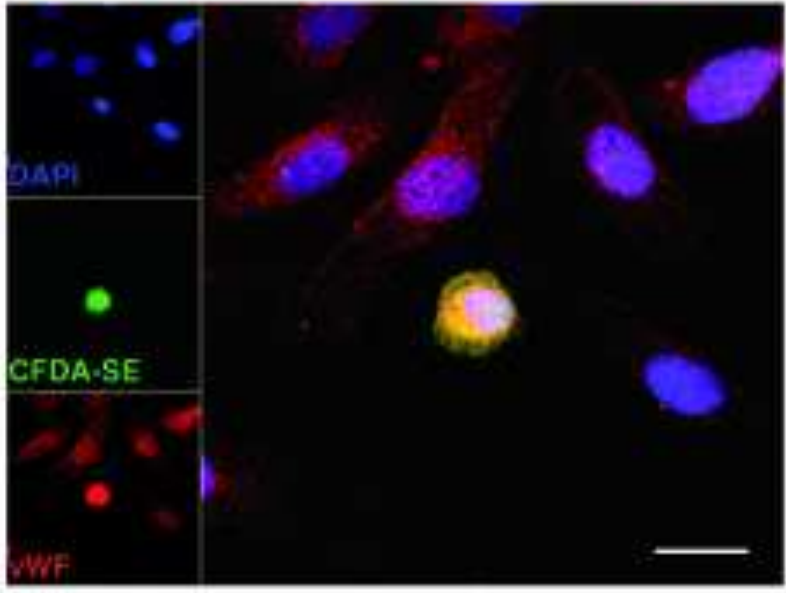

D

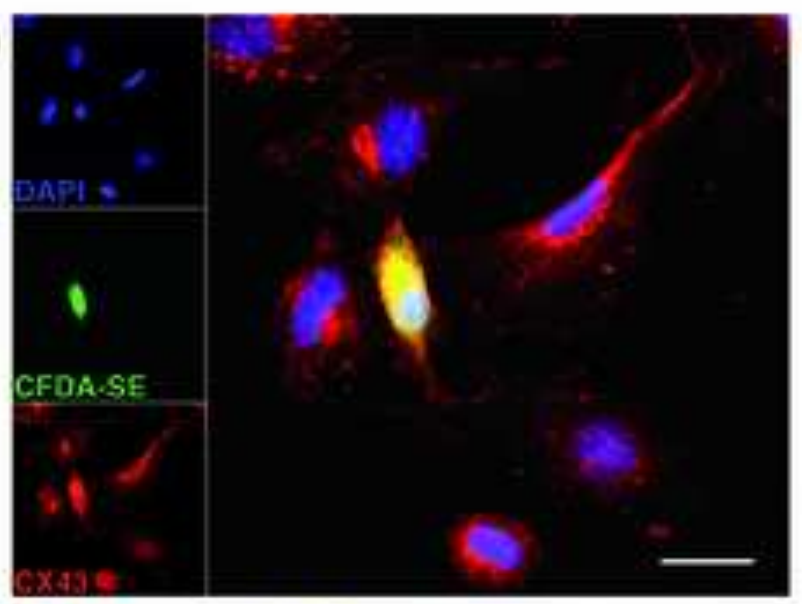

F

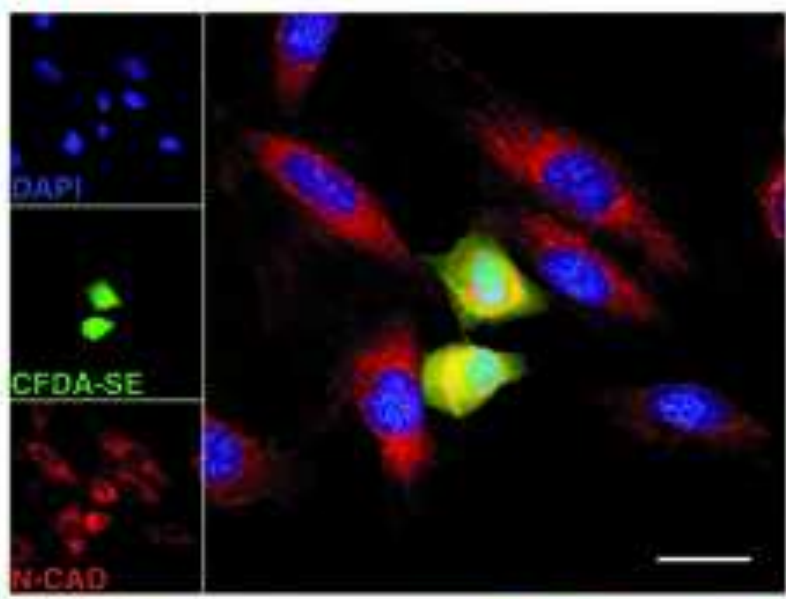

$\mathrm{H}$

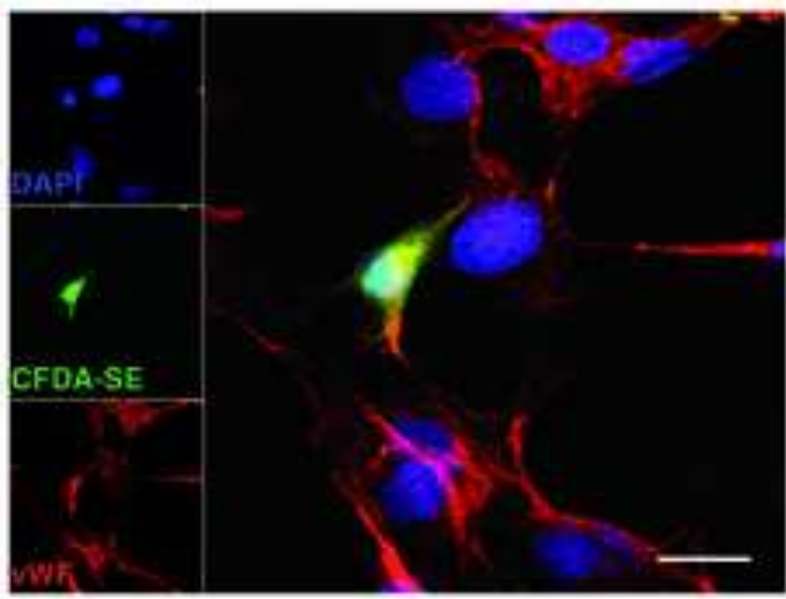



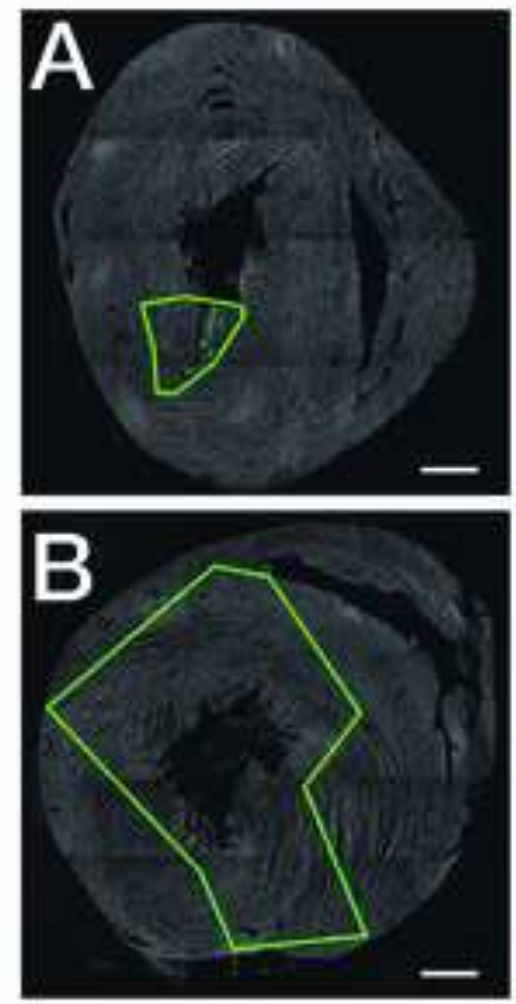

E
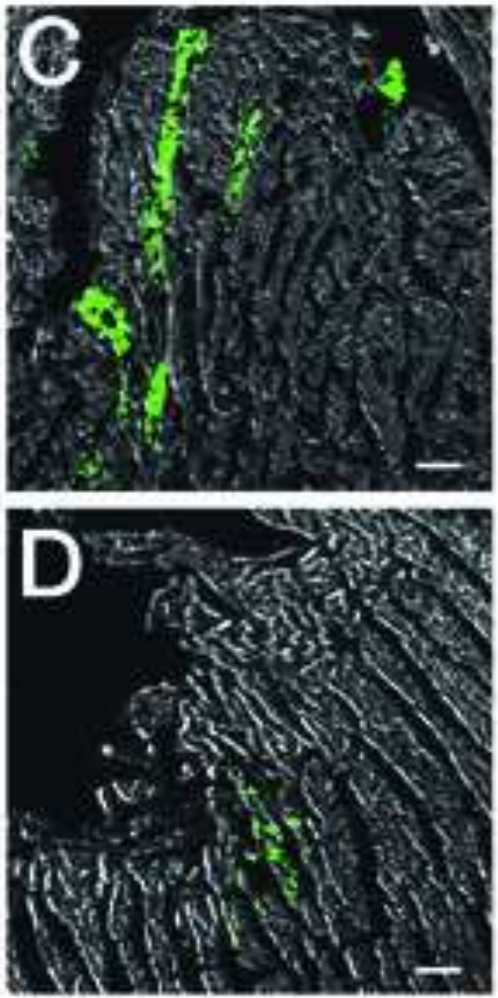

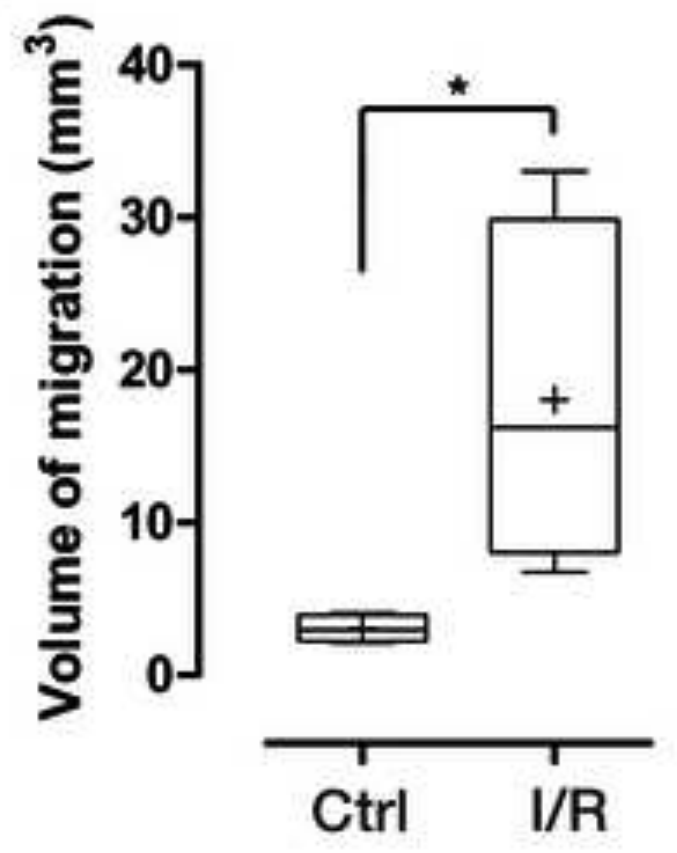

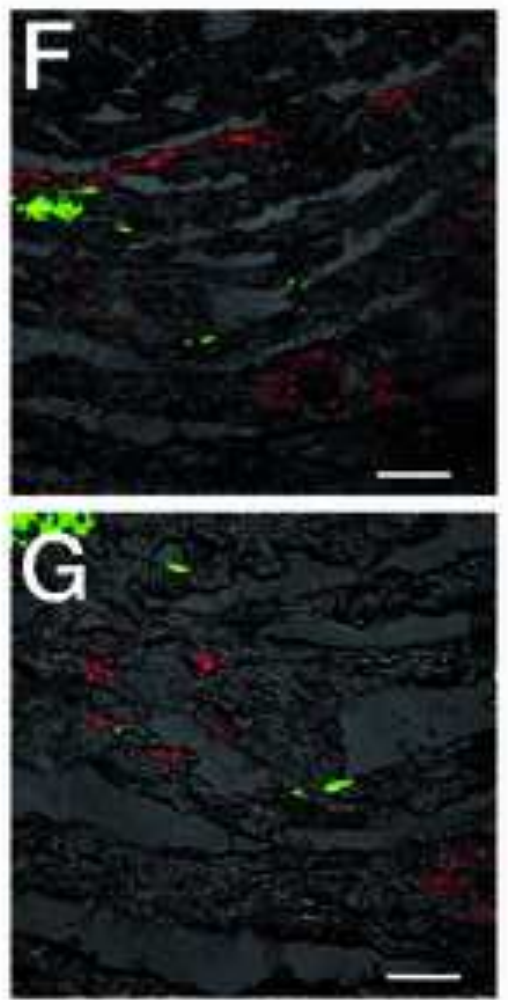



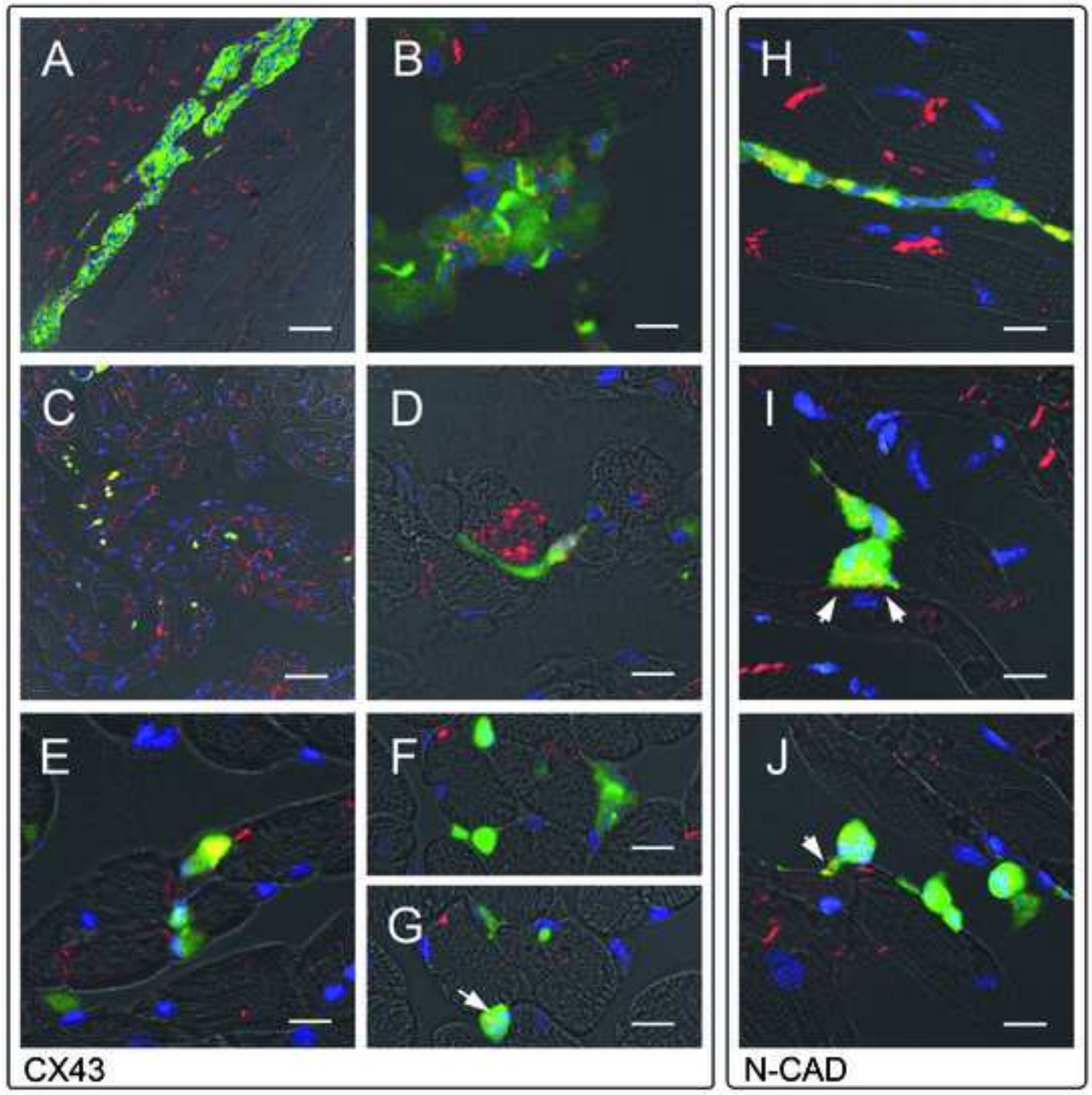

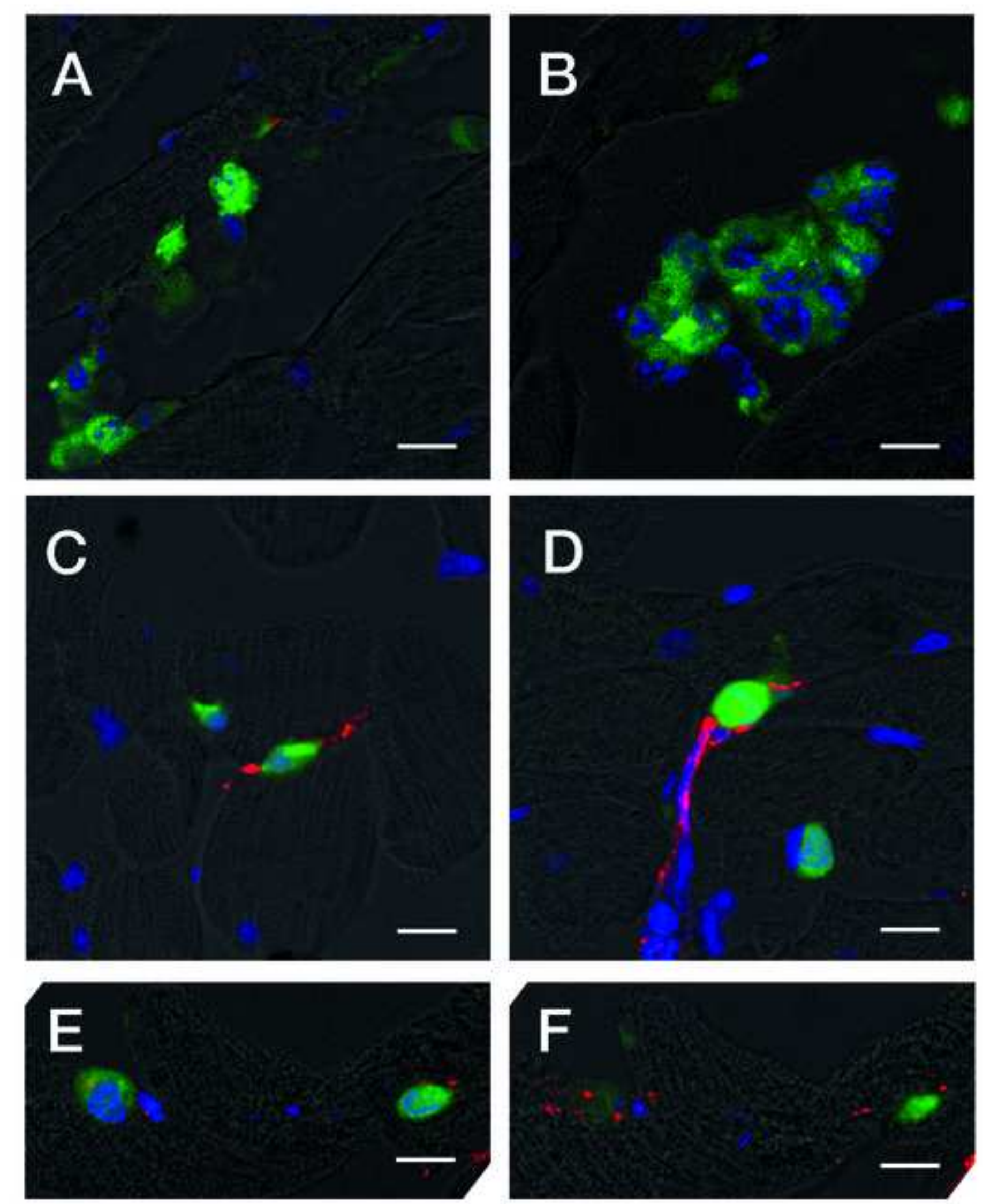

\section{F}



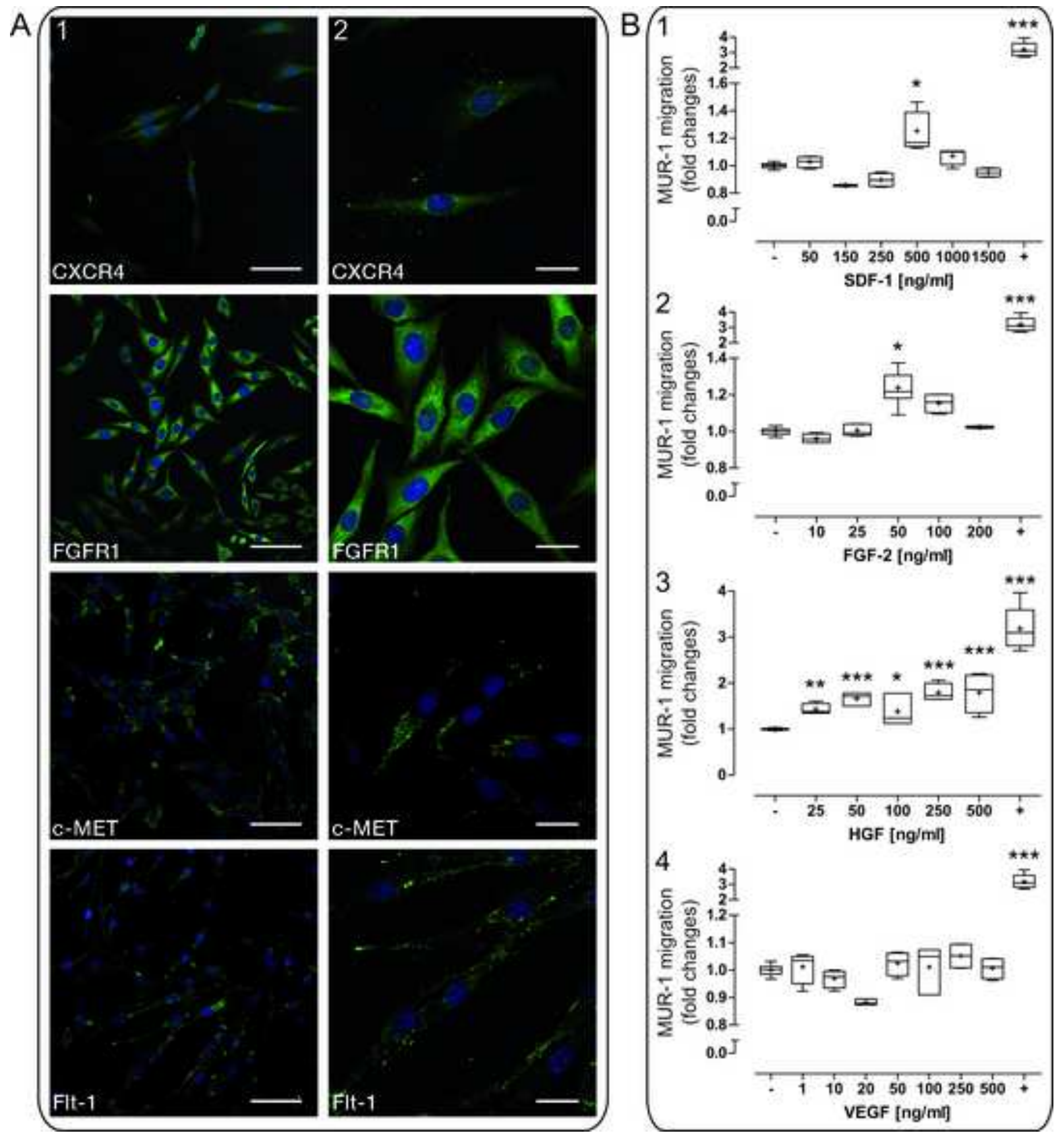